\title{
Neurofunctional activation patterns reflect differences in cognitive control associated with spelling skills in Spanish
}

\author{
Alicia Martínez-Ramos ${ }^{1,2 \star}$, Fabiola R. Gómez-Velázquez¹, Maribel Peró-Cebollero³, \\ Andrés A. González-Garrido ${ }^{1}$, Joan Guàrdia-Olmos ${ }^{3}$, Esteve Gudayol-Ferré4, and \\ Geisa B. Gallardo-Moreno ${ }^{1}$ \\ ${ }^{1}$ Instituto de Neurociencias, CUCBA; ${ }^{2}$ Department of Neurosciences, CUCS, Universidad de Guadalajara. Guadalajara, Mexico; ${ }^{3}$ Department of \\ Social and Cuantitative Psychology, Universidad de Barcelona. Barcelona. España; ${ }^{4}$ Faculty of Psychology, Universidad Michoacana de San Nicolás \\ de Hidalgo. Hidalgo, Mexico
}

\begin{abstract}
Introduction: There is an essential relationship between reading development and orthographic knowledge, which varies depending on a language's orthographic characteristics. In transparent orthographies, such as Spanish, that relationship is closer, where reading speed and orthographic knowledge reflect the automation of the process in which crucial participation of attention networks is assumed. Objective: The objective of this study is to compare behavioral performance and patterns of cerebral functional activity while subjects with high and low orthographic knowledge perform an attentional control task involving word recognition. Methods: Thirty right-handed participants, aged between 17 and 20 years, were selected through non-probabilistic sampling and then classified into two groups according to their level of orthographic knowledge: high (H) and low (L). Neurofunctional activity was recorded using fMRI methods during the execution of a Stroop task (words printed in color congruent and incongruent with their meaning) under two conditions: attending to the meaning (automatic processing) or the color (interference condition). Results: The $L$ group showed greater reaction times in both conditions, as well as greater functional activity in subcortical areas. In contrast, the $\mathrm{H}$ group showed higher activity in cortical areas, such as left supramarginal gyrus and medial frontal gyrus in the automatic processing condition, and in the parietal lobe during interference. Conclusions: The more significant activity in the giro frontal medial of the high orthographic knowledge group could imply recruitment of greater attention and cognitive control resources, while the neurofunctional activity observed in the low group could be associated with a compensatory effect with the recruitment of subcortical areas to solve the task.
\end{abstract}

Key words: Orthographic knowledge. Stroop task. Attentional control. Functional magnetic resonance imaging. Reading.

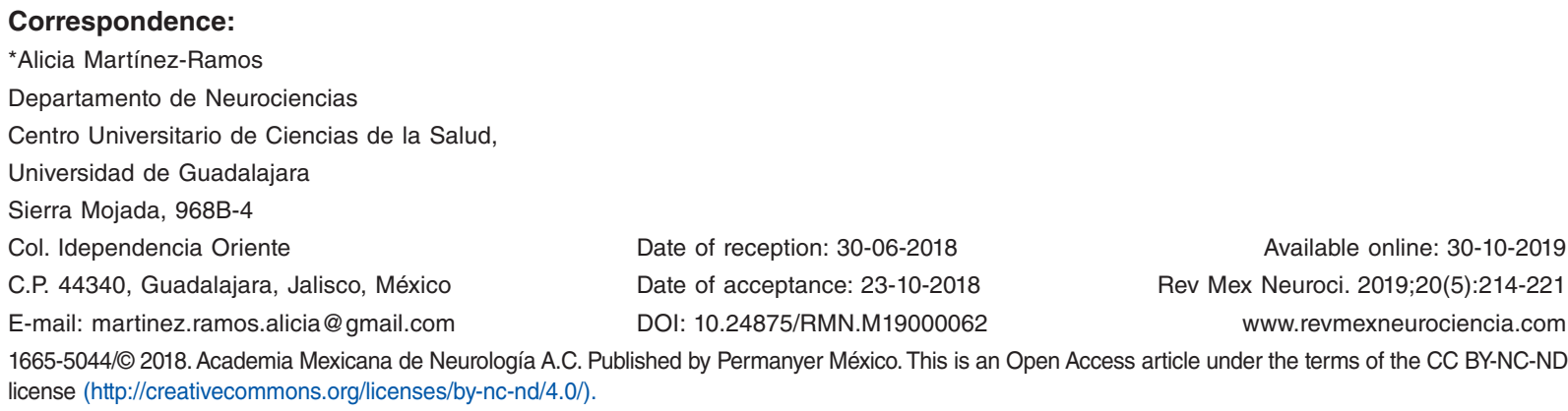

Date of reception: 30-06-2018

Date of acceptance: 23-10-2018

DOI: 10.24875/RMN.M19000062 1665-5044/O 2018. Academia Mexicana de Neurología A.C. Published by Permanyer México. This is an Open Access article under the terms of the CC BY-NC-ND license (http://creativecommons.org/licenses/by-nc-nd/4.0/). 


\section{La actividad funcional cerebral caracteriza el control cognitivo asociado a habilidades ortográficas en el idioma español}

\section{Resumen}

Introducción: Existe una importante relación entre el desarrollo de la lectura y el conocimiento ortográfico, la cual varía en dependencia de las características ortográficas de la lengua. En ortografías transparentes, como el español, esa relación es más estrecha, donde la velocidad de lectura y el conocimiento ortográfico reflejan la automatización del proceso, en la que se asume una participación importante de las redes atencionales. Objetivo: Comparar los patrones de actividad funcional cerebral en una tarea de control atencional que involucra el reconocimiento de palabras, en sujetos con alto y bajo conocimiento ortográfico. Método: Se usó un muestreo no probabilístico para seleccionar a 30 jóvenes, diestros, en un rango de edad entre 17 y 20 años, clasificados en dos grupos de acuerdo con su nivel de conocimiento ortográfico: alto y bajo. Se registró la actividad neurofuncional usando IRMf, durante la ejecución de una tarea de Stroop (palabras impresas en color congruente e incongruente con su significado). Los participantes procesaron las palabras en dos condiciones: atender al significado (procesamiento automático) o al color (condición de interferencia). Resultados: El grupo con «bajo» rendimiento ortográfico mostró mayores tiempos de reacción en la ejecución de ambas condiciones, así como mayor actividad funcional en áreas subcorticales. El grupo alto mostró la actividad esperada en áreas corticales como el giro supramarginal izquierdo (GSI) y giro frontal medial (GFM) durante el procesamiento automático de las palabras, mientras que en la condición de interferencia se observó mayor actividad en lóbulo parietal. Conclusiones: Diferencias en las habilidades ortográficas derivan en distinta activación funcional, donde una mayor actividad en GFM del grupo «alto» pudiera implicar el reclutamiento de mayores recursos atencionales y de control cognitivo, mientras que la actividad neurofuncional observada en el grupo «bajo», podría asociarse con un efecto compensatorio con el reclutamiento de áreas subcorticales para resolver la tarea.

Palabras clave: Conocimiento ortográfico. Stroop. Control atencional. IRMf. Lectura.

\section{Introduction}

Reading automation is a complex developmental process that makes reading faster and less effortful, while minimizing attention and memory requirements consequently enhancing reading comprehension. There is a close relationship between reading and orthographic integration which seems to depend on the orthographic transparency of the language ${ }^{1,2}$. In transparent orthographies, such as Spanish, where there is a close relationship between graphemes and phonemes, impairments in reading speed and spelling problems occur frequently, and these orthographic difficulties may endure into adulthood $^{3-5}$.

Despite increasing evidence regarding reading fluency and orthographic abilities in children, few studies have explored this association in late adolescence and adulthood. A recent study performed in Spanish-speaking young adults reported significant supramarginal and angular gyrus activations while actively recognizing orthographic errors ${ }^{6}$. These regions are involved in the interactions between the phonologic and orthographic representations of words ${ }^{7}$.

An emerging question in the current psycholinguistic research is how attentional control systems can influence specific components of the lexical processing system.
In this regard, skilled reading in adults has been extensively studied using variations of the Stroop task ${ }^{8,9}$. The incongruence between word meaning and the color in which a word is printed usually elicits slower response times due to interference with the automatic word-recognition process, and the Stroop interference effect has been related to attentional control.8,10-12 The left medial frontal gyrus (MFG) plays an important role in attentional control via a top-down biasing when selecting task-relevant stimuli and through inhibition of task-irrelevant stimuli $i^{13}$. In this context, the aim of the present study was to comparatively evaluate behavioral and brain activation patterns during performance of a Stroop task in a sample of young adult readers with different levels of orthographic processing skills, in order to discern whether the lower level of reading automation seen in individuals with low orthographic skills associates with attentional control and mapping processes between phonological and orthographic word representations.

\section{Methods}

\section{Participants}

A non-probabilistic convenience sampling method was used for the assessment. Thirty young adults 
Table 1. Demographic data, orthographic knowledge, and behavioral results while performing the experimental task

\begin{tabular}{|c|c|c|c|c|}
\hline & HSS & LSS & $t$ (df) & $\mathbf{p}$ \\
\hline & Mean (SD) & Mean (SD) & & \\
\hline $\begin{array}{l}\text { Demographic data } \\
\text { Age } \\
\text { Estimated I0 }\end{array}$ & $\begin{array}{l}18.6(0.98) \\
107.7(8.8)\end{array}$ & $\begin{array}{l}18.7(0.90) \\
101.3(5.2)\end{array}$ & $\begin{array}{c}t(27.7)=-0.2 \\
t(22.5)=2.4\end{array}$ & $\begin{array}{l}\text { n.s. } \\
\text { n.s. }\end{array}$ \\
\hline $\begin{array}{l}\text { Orthographic knowledge } \\
\text { Reading speed } \\
\text { Reading errors } \\
\text { Reading comprehension } \\
\text { Orthographic errors }\end{array}$ & $\begin{array}{c}165.3(23.8) \\
0.9(1.7) \\
7.9(2.1) \\
7.2(3.0)\end{array}$ & $\begin{array}{c}133.6(25) \\
8.5(6.1) \\
6.6(2.4) \\
35.2(0.7)\end{array}$ & $\begin{array}{c}t(20.4)=4.4 \\
t(16.2)=-4.6 \\
t(27.3)=1.6 \\
t(15.4)=-34.9\end{array}$ & $\begin{array}{l}<0.001 \\
<0.001 \\
\text { n.s. } \\
<0.001\end{array}$ \\
\hline $\begin{array}{l}\text { Interference task results } \\
\text { Word meaning correct responses } \\
\text { Word color correct responses } \\
\text { Word meaning reaction time } \\
\text { Word color reaction time }\end{array}$ & $\begin{array}{c}33.2(6.9) \\
35.2(5.5) \\
780.5(88.8) \\
770.5(112.7)\end{array}$ & $\begin{array}{c}33.1(5.8) \\
35.9(2.3) \\
855.1(103.9) \\
842.7(108.7)\end{array}$ & $\begin{array}{l}t(28)=0.02 \\
t(28)=-0.4 \\
t(28)=-2.1 \\
t(28)=-1.8\end{array}$ & $\begin{array}{l}\text { n.s. } \\
\text { n.s. } \\
0.044 \\
\text { n.s. }\end{array}$ \\
\hline
\end{tabular}

df: degrees of freedom; SD: standard deviation; n.s.: not significant.

whose ages ranged from 17 to 20 years $(\mathrm{M}=18.63$ years, $\mathrm{SD}=0.928 ; 10$ females) participated during 2017; all were right-handed as assessed by the Edinburgh Handedness Inventory and had normal or corrected-to-normal vision ${ }^{14}$. None had any personal or family history of psychiatric, neurological, or degenerative illness, nor diagnoses of ADHD, emotional disturbances, or behavioral disorders, according to the DSM-V criteria ${ }^{15}$. They all signed an informed consent form and received economic compensation for their participation, following permission and recommendations of the Ethics Committee of the Instituto de Neurociencias (Universidad de Guadalajara), which approved the study.

The sample was obtained from a pool of 380 students in the final year of high school (public) or the first semester at a public university. Participants were divided into two groups according to their performance on four orthographic knowledge tasks from the Batería de Conocimiento Ortográfico (BCO, orthographic knowledge test $)^{16}$. These tasks involved word completion (complete words by choosing between two or three homophone letters), text dictation (a narrative text in the form of a letter), word dictation (a list of 40 words all susceptible to pseudohomophone errors), and text correction exercises (an expository text in which 22 words were replaced by pseudohomophonic errors). The BCO is a four-test battery validated for high school students, with a Cronbach's internal consistency reliability of $\alpha=0.859$, and a construct validity analysis showing that all tests contribute to a single construct that explains $71 \%$ of total variability. A previous study with a sample of 827 native Spanish-speaking young adults demonstrated that BCO had a very high discriminability in terms of distinguishing groups with different orthographic abilities $(t=11.608 ; p<0.001)^{16}$.

Groups were formed as follows: high spelling skills (HSS), 15 participants (6 females) with fewer errors than those corresponding to the $10^{\text {th }}$ percentile of the standardized BCO scores, and low spelling skills (LSS), 15 participants (4 females) with a number of errors above the $90^{\text {th }}$ percentile. All subjects had a global $I Q \geq 90$ as measured by a short version of the Wechsler Adult Intelligence Scale $\mathrm{III}^{17}$. Due to excessive head movements during the functional magnetic resonance imaging (fMRI) recording session, one female participant from the LSS group had to be excluded from further analysis.

The groups were matched according to age and educational level. All participants underwent an extensive clinical interview before the experimental sessions. Prior to the neuroimaging studies, and due to the strong relationship found between spelling difficulties and low reading fluency, we decided to explore whether LSS also had problems related to reading accuracy or speed $^{18}$. Consequently, all subjects were asked to read aloud an expository text of 504 words as quickly and accurately as possible. Table 1 shows the demographic characteristics, orthographic knowledge profiles, and reading test performance of all subjects.

During the MRI scan session, participants performed a variant of the Stroop task in which the words green, blue, and red appeared printed in congruent or 


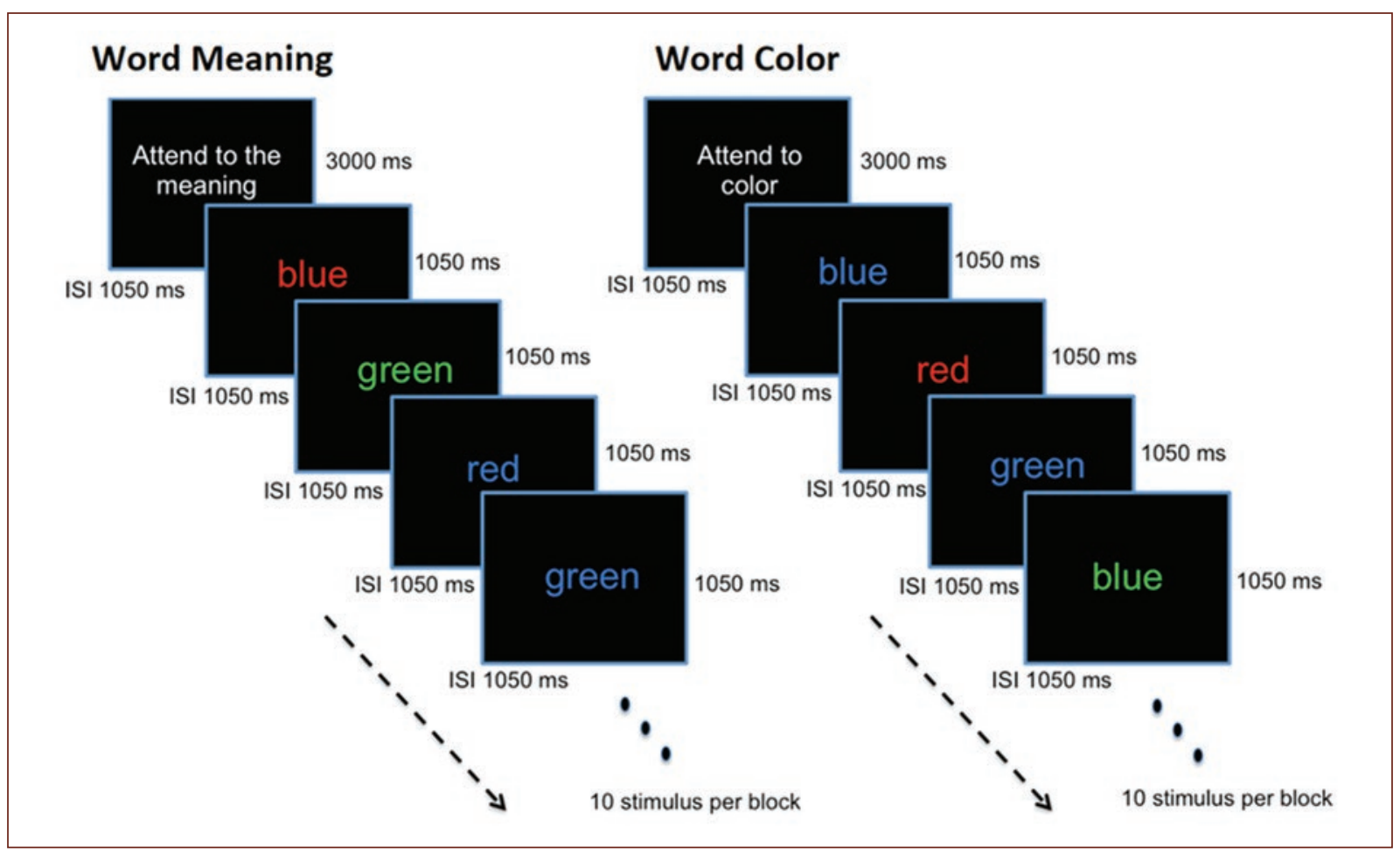

Figure 1. Experimental flowchart. In word meaning, the participants are instructed to press one button to identify the color denoted by the word presented on the screen. In word color, they are instructed to press the button that corresponds to the color in which the word shown is printed (e.g., when the word red appears printed in blue, the subject should press the button that corresponds to the blue option).

incongruent colors. The tasks were identified as word meaning and word color, and their presentation order was counterbalanced. In word meaning, subjects had to read the word and identify its meaning by pressing a corresponding button. In word color, they were instructed to press a button that indicated the color in which the word was printed while ignoring the meaning of the word that appeared. Figure 1 illustrates the experimental design.

\section{Procedure}

During the fMRI scans, the stimuli were administered using E-Prime Studio v.2.0 (Psychology Software Tools, Inc., 2010). Images were projected through a Google system, and responses were collected using a magnetic -resonance-compatible, handheld, four-button response pad connected to the computer by an optical cable interface.

Days before the scanning session, task instructions were presented and explained to the subjects during their assessment session. Subjects then performed several series of training trials with feedback provided to familiarize them with the task. All subjects were instructed as to the arrangement of the keypad buttons, which represented green, blue, and red from left to right. They were told to use the index, middle, and ring fingers of their right hand to respond. They were also instructed to respond as quickly as possible while keeping in mind that the main goal was to perform the tasks correctly.

Both tasks were administered through a block design with 8 activation blocks. Blocks were separated by resting periods. During the resting periods, the participant focused on a fixation point presented at the center of the screen. Prior to each activation block, an instruction lasting $3000 \mathrm{~ms}$ was presented. Both stimulus and interstimulus intervals lasted $1050 \mathrm{~ms}$, resulting in 80 trials with a total duration of 6 min $12 \mathrm{~s}$ and 10 stimuli per active block (Fig. 1). A total of 124 brain volumes were obtained from each experimental task, but 12 were eliminated from the subsequent statistical analysis. The first two volumes discarded contained the warnings that preceded the beginning of the task. Furthermore, the volumes corresponding to the instructions preceding each of the 8 active blocks were deleted. The other 2 discarded volumes were those used to inform subjects that they had completed the task. 


\section{Image acquisition}

A GE Excite HDxT 1.5 Tesla device (GE Medical Systems, Milwaukee, WI, USA) with an 8-channel head coil was used. For each experimental task, 32 contiguous axial slices were obtained ( $4 \mathrm{~mm}$ thick). An echo-planar pulse sequence was used with a repetition time of $3 \mathrm{~s}$, echo time of $60 \mathrm{~ms}$, flip angle of $90^{\circ}$, FOV of $25.6 \mathrm{~cm}$, and a $64 \times 64$ matrix. Voxel size was $4 \times 4 \times 4 \mathrm{~mm}$.

\section{Data analysis}

The demographic and behavioral results were analyzed using SPSS 20.0. An Independent Samples t-test was performed to compare the two conditions within the groups. Spatial preprocessing and statistical inference of the images were carried out using the SPM12 computer package (http://www.fil.ion.ucl. ac.uk/spm/software/spm12/). The images were spatially realigned, readjusted to the voxel size, and normalized in accordance with the Montreal Neurological Institute reference. For smoothening, a kernel Gaussian filter 3 times the voxel size was used on the $x$, $y$, and $z$ axes.

Brain activations in response to the two conditions were examined by performing a first-level general linear model (GLM) analysis for each subject using a statistical threshold of $p=0.05$. To compare activation patterns between the groups and conditions, a second-level GLM analysis was conducted using the same statistical threshold for cluster level and applying posterior correction with a Bonferroni procedure to reduce nominal type I error.

\section{Results}

\section{Reading performance}

Reading performance was analyzed by an independent t-test, assuming equal variances (Levene test: $F=0.808 ; p=0.376)$. A significant difference in reading speed was found between the groups ( $t(20.4)=4.4 ; p=0.001 ; r=0.639$ ), with a greater number of words per minute and fewer reading errors in HSS than LSS (Table 1).

With respect to reading comprehension, and assuming equal variances (Levene test: $F=1.073$; $p=0.309$ ), no significant differences were found between the groups $(t(27.3)=1.60 ; p=0.119 ; r=0.289)$, though the number of correct responses achieved by HSS was slightly higher than in LSS.

\section{Behavioral paradigm results}

For the experimental task, we analyzed two variables using independent t-tests: the number of correct responses and response times (RTs). We only found significant between-group differences in the RT word meaning condition ( $\mathrm{t}(28)=-2.11 ; \mathrm{p}=0.044: \mathrm{r}=0.361$ ), assuming equal variances (Levene test: $F=.592 ; p=0.448$ ). LSS showed slower RT in both conditions (word meaning and word color) than HSS, but only RT during word meaning differed significantly. Accuracy between the groups, in contrast, was similar in both conditions (Table 1).

\section{Neuroimaging results}

Tables 2 and 3 show the main activation clusters observed in the experimental groups during task performance. As was expected, main between-group differences involved the left supramarginal gyrus (LSG) and MFG, both of which were highly activated in HSS during recognition of word meaning. This group also involved the superior parietal lobe together with other right cortical structures while processing the word interference task (word color). In contrast, LSS did not show significant activations at LSG and MFG while performing the experimental tasks. Predominantly, LSS showed subcortical activations, primarily involving cerebellar structures. Figure 2 shows the main BOLD activated structures in both the groups while processing the word meaning and word color task sections, respectively.

\section{Discussion}

The present study evaluated the behavioral and brain activation patterns of Spanish-speaking young readers with different levels of orthographic processing skills during performance of an interference task. One of our objectives was to assess whether lower orthographic processing skills in Spanish might reflect a deficit in attentional control.

At first, and unsurprisingly, LSS showed slower reading speeds, thus confirming the significant relationship between spelling knowledge and reading speed reported for transparent orthographies ${ }^{3,19}$. Both spelling performance and reading speed are important factors for the development of reading and writing. In addition, several studies have observed problems in spelling and reading speed in subjects with reading disorders, even in adults who had reached high educational levels ${ }^{20,21}$. It has been proposed that these problems may be due to a unique mechanism that underlies the ability to store 
Table 2. Brain functional activations per condition in the high skill spelling group

\begin{tabular}{|c|c|c|c|c|c|c|c|c|}
\hline \multirow[t]{2}{*}{ Task } & \multirow[t]{2}{*}{ Cluster } & \multirow[t]{2}{*}{ Z } & \multicolumn{3}{|c|}{ MNI coordinates } & \multirow[t]{2}{*}{ H } & \multirow[t]{2}{*}{ Brain region } & \multirow[t]{2}{*}{ Brodmann area } \\
\hline & & & $x$ & $y$ & z & & & \\
\hline \multirow{5}{*}{$\begin{array}{l}\text { Word } \\
\text { meaning }\end{array}$} & 1532 & 4.36 & -46 & -32 & 46 & L & Supramarginal gyrus; Middle frontal gyrus & 40,6 \\
\hline & 464 & 3.74 & 6 & -60 & -22 & $\mathrm{R}$ & $\begin{array}{l}\text { Cerebellar culmen (anterior lobe); Cerebellar } \\
\text { tonsil (posterior lobe) }\end{array}$ & * \\
\hline & 197 & 3.00 & 50 & 12 & 18 & $\mathrm{R}$ & Inferior frontal gyrus; Middle frontal gyrus & $6,44,46$ \\
\hline & 120 & 3.00 & 38 & -56 & 46 & $\mathrm{R}$ & Supramarginal gyrus; Superior parietal lobule & 40,7 \\
\hline & 115 & 2.34 & -38 & -64 & -30 & $\mathrm{~L}$ & Cerebellar tuber; cerebellar declive (posterior lobe) & * \\
\hline \multirow{4}{*}{$\begin{array}{l}\text { Word } \\
\text { color }\end{array}$} & 1821 & 5.42 & -42 & -32 & 46 & $\mathrm{~L}$ & Supramarginal gyrus; Superior parietal lobule & 40,7 \\
\hline & 1089 & 4.59 & 38 & -60 & -30 & $\mathrm{R}$ & $\begin{array}{l}\text { Cerebellar tuber (posterior lobe); Cerebellar } \\
\text { pyramid (anterior lobe) }\end{array}$ & * \\
\hline & 270 & 4.00 & 38 & -56 & 50 & $\mathrm{R}$ & Superior parietal lobule; Inferior parietal lobule & 7,40 \\
\hline & 234 & 3.43 & 58 & 12 & 34 & $\mathrm{R}$ & Middle frontal gyrus & 9,6 \\
\hline
\end{tabular}

$\mathrm{H}$ : hemisphere; L: left; R: right.

Table 3. Brain functional activations per condition in the low skill spelling group

\begin{tabular}{|c|c|c|c|c|c|c|c|c|}
\hline \multirow[t]{2}{*}{ Task } & \multirow[t]{2}{*}{ Cluster } & \multirow[t]{2}{*}{$\mathbf{Z}$} & \multicolumn{3}{|c|}{ MNI coordinates } & \multirow[t]{2}{*}{ H } & \multirow[t]{2}{*}{ Brain region } & \multirow[t]{2}{*}{ Brodmann area } \\
\hline & & & $\mathbf{x}$ & y & $\mathbf{z}$ & & & \\
\hline \multirow[t]{3}{*}{$\begin{array}{l}\text { Word } \\
\text { meaning }\end{array}$} & 113 & 2.76 & 18 & -60 & -26 & $\mathrm{R}$ & $\begin{array}{l}\text { Cerebellar dentate (anterior lobe); Cerebellar } \\
\text { pyramid (posterior lobe) }\end{array}$ & * \\
\hline & 11 & 2.12 & -42 & -56 & -26 & $\mathrm{~L}$ & Cerebellar tuber & * \\
\hline & 10 & 2.01 & -34 & 16 & -6 & $\mathrm{~L}$ & Inferior frontal gyrus & 47 \\
\hline \multirow[t]{3}{*}{ Word color } & 423 & 3.67 & 26 & -52 & -34 & $\mathrm{R}$ & Cerebellar tonsil; Cerebellar inferior semilunar lobe & * \\
\hline & 38 & 2.69 & -34 & 0 & 22 & $\mathrm{~L}$ & Precentral gyrus; Superior temporal gyrus & 6,22 \\
\hline & 41 & 2.29 & 34 & 24 & -6 & $\mathrm{R}$ & Inferior frontal gyrus & 47 \\
\hline
\end{tabular}

H: hemisphere; L: left; R: right.

representations of the written form of words in long-term memory and thus facilitates the process of reading and the efficient recovery of that material ${ }^{22}$.

Paradoxically, there were no significant interference effects during the word color assignment in either group. Here, several factors may have been involved: the low number of stimuli; the training received before task performance; the time that each word was shown; the way in which the stimuli were delivered; and the response modality of button pressing which is different from a typical Stroop task in which words/colors are produced aloud, among several other possible influences. Having said this, the behavioral results obtained while performing the MRI scanning may not comparably reflect what a representative Stroop task performance might yield under regular conditions.

Turning to our behavioral results, LSS showed significantly longer reaction times than HSS during both the word meaning and word color tasks. Given that slow reading speed is the core element of reading disabilities in Spanish, LSS' performance in our study seems to coincide with previously reported findings in people with reading disorders $9,10,23,24$.

Taken together, the results of the present study suggest that slower performance observed in LSS might extend to non-linguistic processing of printed words and probably reflects an additional deficit in the mechanisms of attentional control. 


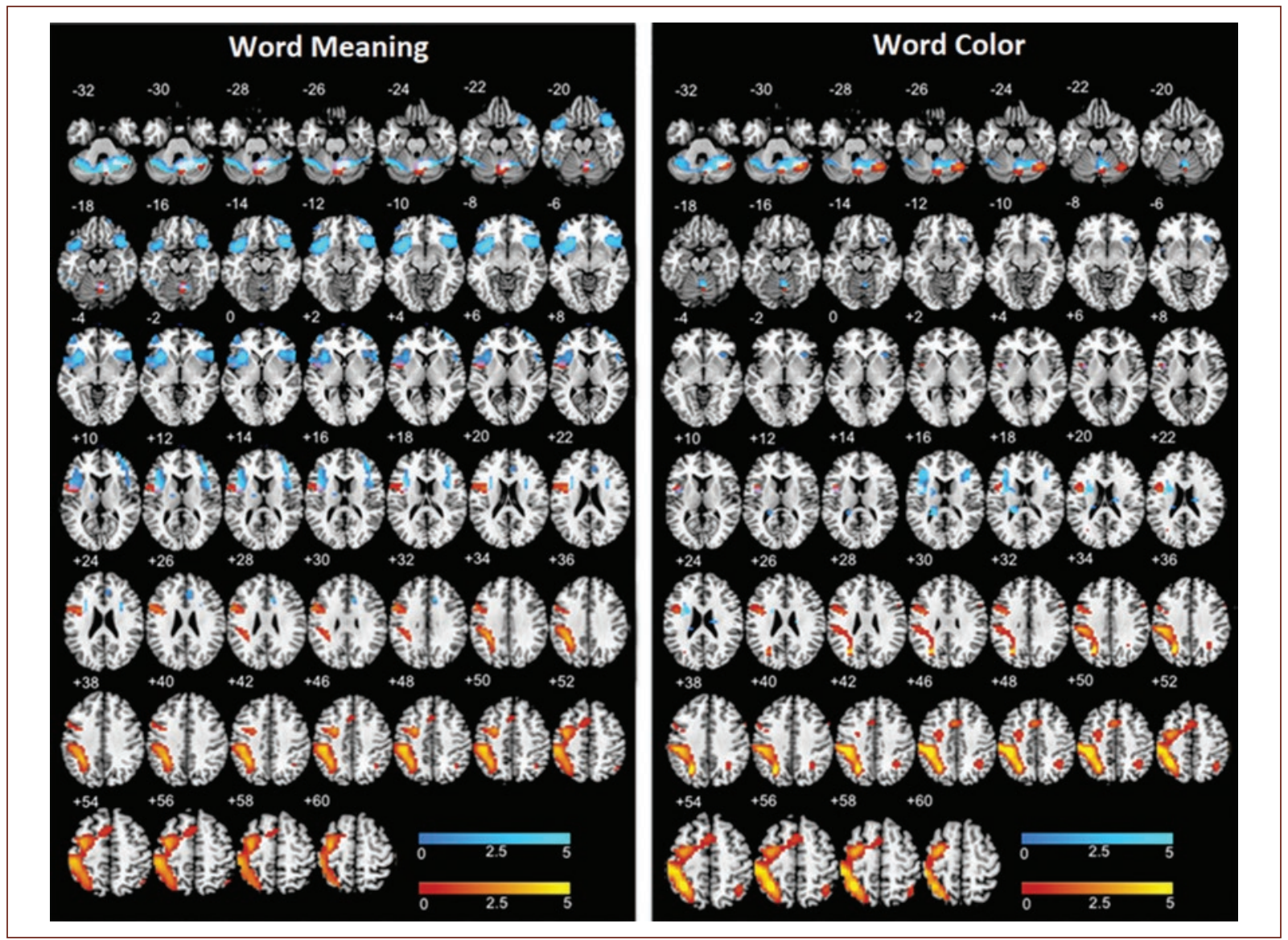

Figure 2. Functional neuroimages for the word meaning and word color conditions. Neurological view (left-right). Redto-white colors represent the statistical activity (z) of the HSS group. Blue-to-white colors represent the statistical activity (z) of the low spelling skills group.

As hypothesized at the outset, neurofunctional correlates of task performance differentially involved the LSG and MFG of the two study groups. This emphasizes that attention and word recognition processes are the main foundations of the more developed spelling abilities in native Spanish-speaking young adults. In contrast, our LSS subjects mainly activated subcortical areas involving cerebellar regions that have been linked to language processes, especially when articulation is a factor to be considered ${ }^{25}$. This also occurs with the insula, another area that has been linked to many linguistic processes, including language production, repetition, and naming ${ }^{26}$.

In fact, our LSS individuals showed significant activations in cerebellar and posterior frontal cortical areas while processing the interference task. These regions have been related to executive functions and attentional control ${ }^{27}$. The left caudate and cerebellum have been associated with the suppression of irrelevant words while performing interference tasks ${ }^{28}$. In addition, the left caudate has been closely associated with the cingulate gyrus (which in turn has been related to conflict monitoring), and with other structures related to perception and the visual recognition of stimuli and letters, including the fusiform, lingual, and inferior occipital gyri2 ${ }^{29}$.

Although the lack of a clear interference effect might limit the scope of the present study, the neurofunctional differences detected between the groups: (1) indicate that both attentional control and word management are involved in solving interference while reading and (2) distinguish the level of orthographic processing in native Spanish-speaking young adults. However, further studies are required to fully understand the relation between these variables in a transparent language such as Spanish.

\section{Conclusions}

The subcortical and cerebellum involvement observed in LSS might reflect an adaptive effort to recruit additional processing resources in order to fulfill task 
requirements. Furthermore, the increased activity observed in the left MFG in HSS might reflect a higher level of attention and cognitive control, as postulated by Egner and Hirsch ${ }^{30}$.

\section{Conflicts of interest}

None of the authors have potential conflicts of interest to be disclosed.

\section{Funding}

The research presented in this paper was supported by grant to second author from SEP-CONACYT Mexico (183561).

\section{References}

1. Berninger VW, Nielsen KH, Abbott RD, Wijsman E, Raskind W. Writing problems in developmental dyslexia: under-recognized and under-treated. J Sch Psychol. 2008;46:1-21.

2. Ehri LC. Learning to read and learning to spell are one and the same, almost. In: Perfetti L, Rieben M, editors. Learning to Spell. $1^{\text {st }}$ ed. Mahwah, NJ: Erlbaum; 1997. p. 237-69.

3. Landerl K. Word recognition deficits in German: more evidence from a representative sample. Dyslexia. 2001;7:183-96.

4. Lovett MW, Ransby MJ, Barron RW. Treatment, subtype, and word type effects in dyslexic children's response to remediation. Brain Lang. 1988;34:328-49

5. Landerl K, Klicpera C. Lese, Rechtschreibstörung. In: Petermann F, editor. Fallbuch der Klinischen Kinderpsychologie. $3^{\text {rd }}$ ed. Göttingen: Hogrefe; 2009.

6. González-Garrido AA, Alejandro Barrios F, Gómez-Velázquez FR, Zarabozo-Hurtado $D$. The supramarginal and angular gyri underlie orthographic competence in Spanish language. Brain Lang. 2017;175:1-0.

7. Booth JR, Burman DD, Meyer JR, Gitelman DR, Parrish TB, Mesulam MM, et al. Development of brain mechanisms for processing orthographic and phonologic representations. J Cogn Neurosci. 2004; 16:1234-49

8. MacLeod CM. Half a century of research on the stroop effect: an integrative review. Psychol Bull. 1991;109:163-203.

9. Protopapas A, Archonti A, Skaloumbakas C. Reading ability is negatively related to stroop interference. Cogn Psychol. 2007;54:251-82.
10. Proulx MJ, Elmasry HM. Stroop interference in adults with dyslexia. Neurocase. 2015;21:413-7.

11. Chen T, Kendrick KM, Feng C, Sun S, Yang X, Wang X, et al. Dissociable early attentional control mechanisms underlying cognitive and affective conflicts. Sci Rep. 2016;6:37633.

12. Chiu YC, Jiang J, Egner T. The caudate nucleus mediates learning of stimulus-control state associations. J Neurosci. 2017;37:1028-38.

13. Thomsen T, Specht K, Rimol LM, Hammar A, Nyttingnes J, Ersland L, et al. Brain localization of attentional control in different age groups by combining functional and structural MRI. Neuroimage. 2004;22:912-9.

14. Oldfield RC. The assessment and analysis of handedness: the Edinburgh inventory. Neuropsychologia. 1971;9:97-113.

15. American Psychiatric Association, editor. Diagnostic and Statistical Manual of Mental Disorders DSM V. $5^{\text {th }}$ ed. Arlington: American Psychiatric Association; 2013. p. 991.

16. Gómez-Velázquez FR, González-Garrido AA, Guárdia-Olmos J, Peró-Cebollero M, Zarabozo-Hurtado D, Zarabozo D. Evaluación del conocimiento ortográfico en adultos jóvenes y su relación con la lectura. Revista De Neuropsicología, Neuropsiquiatría Y Neurociencias. 2014;14:40-67.

17. Wechsler D. WAIS-III. Escala Wechsler de Inteligencia para Adultos-III. México: Manual Moderno; 2003.

18. Holmes VM, Malone AM, Redenbach H. Orthographic processing and visual sequential memory in unexpectedly poor spellers. J Res Read. 2008;31:136-56.

19. Goswami U. The development of reading across language. N Y Acad Sci. 2008;11:1-12

20. Re AM, Tressoldi PE, Cornoldi C, Lucangeli D. Which tasks best discriminate between dyslexic university students and controls in a transparent language? Dyslexia. 2011;17:227-41

21. Undheim AM. A thirteen-year follow-up study of young Norwegian adults with dyslexia in childhood: reading development and educational levels. Dyslexia. 2009;15:291-303.

22. Ehri LC. Learning to read words: theory, findings and issues. Sci Stud Read. 2005;9:167-88.

23. Serrano F, Defior S. Dyslexia speed problems in a transparent orthography. Ann Dyslexia. 2008;58:81-95.

24. Faccioli C, Peru A, Rubini E, Tassinari G. Poor readers but compelled to read: stroop effects in developmental dyslexia. Child Neuropsychol. 2008;14:277-83.

25. Fiez JA, Raichle ME. Linguistic processing. Int Rev Neurobiol. 1997;41:233-54.

26. Ardila A, Bernal B, Rosselli M. Participation of the insula in language revisited: a meta-analytic connectivity study. J Neurolinguistics. 2014;29:31-41.

27. Stoodley CJ, Schmahmann JD. Functional topography in the human cerebellum: a meta-analysis of neuroimaging studies. Neuroimage. 2009;44:489-501.

28. Ali N, Green DW, Kherif F, Devlin JT, Price CJ. The role of the left head of caudate in suppressing irrelevant words. J Cogn Neurosci. 2010;22:2369-86.

29. Robinson JL, Laird AR, Glahn DC, Blangero J, Sanghera MK, Pessoa L, et al. The functional connectivity of the human caudate: an application of meta-analytic connectivity modeling with behavioral filtering. Neuroimage. 2012;60:117-29.

30. Egner T, Hirsch J. The neural correlates and functional integration of cognitive control in a stroop task. Neuroimage. 2005;24:539-47. 